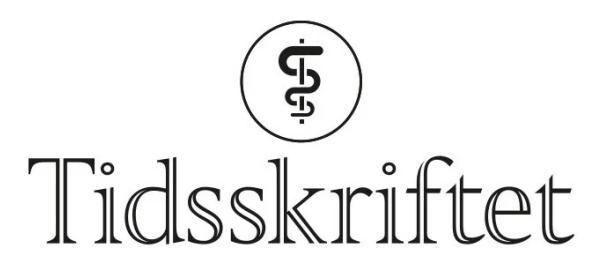

DEN NORSKE LEGEFORENING

\title{
Eivind Andreas Warberg
}

MINNEORD

TOM NORDBY

CARINA LINCHAUSEN

PETER RANCINGER

AXEL BENDIKSBY

VILDE V. LØGAVLEN

AIRAZAT M. KAZARYAN

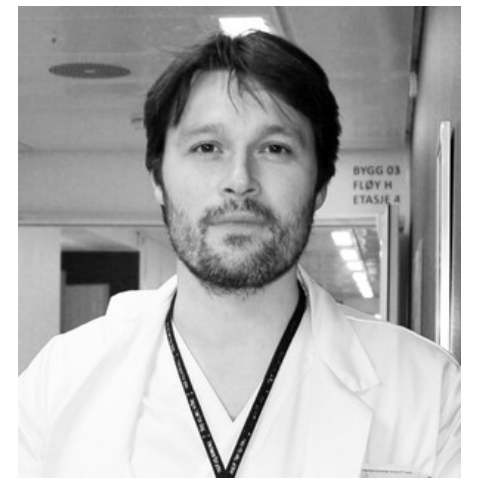

Eivind Andreas Warberg gikk bort 25. juli 2021 etter en drukningsulykke på Færøyene. Han ble 45 år gammel. Eivind født i Bergen i 1976 og vokste opp på Færøyene. Han tok medisinsk embetseksamen ved Københavns Universitet i 2005.

Han arbeidet på den kirurgiske avdelingen ved Landssjúkrahúsið i Tórshavn, Færøyene i 2006-o8 samt på Kirurgisk afdeling C, Rigshospitalet i København 20o8, før han flyttet til Norge og ble ansatt ved Kirurgisk avdeling, Sykehuset Østfold i 2008. Siden da har han arbeidet på Sykehuset Østfold, i tillegg til deltidsjobb for Volvat. Eivind ble spesialist i generell kirurgi i 2015 og i gastroenterologisk kirurgi i 2016, og jobbet også ved Ullevål og Rikshospitalet i spesialiseringstiden. 
Eivind var en glimrende kirurg og omsorgsfull lege, en varm og hjelpsom kollega og veileder. Han var en rollemodell for en generasjon av yngre kirurger ved Sykehuset $\emptyset$ stfold. Døren til Eivinds kontor sto alltid åpen, og han nølte aldri med å dele av egen kunnskap, erfaring og visdomsord. Han dyttet sine yngre kolleger opp og frem og ønsket at de skulle bli enda bedre enn han selv.

Eivind tok initiativ til å innføre ERAS (Enhanced Recovery After Surgery)-protokoll ved Kirurgisk avdeling. Dette ledet til etablering av Sykehuset Østfold som Center of Excellence, det eneste i Norge.

Han var medlem av prosjektgruppen LapcoNor, som har bidratt til opplæring og introduksjon av laparoskopisk kolorektal kirurgi i Norge. Han satt også i styret for Norsk forening for gastroenterologisk kirurgi. I tillegg skrev han flere vitenskapelige artikler og bidro med faglige kommentarer i flere internasjonale tidsskrifter, blant dem verdenskjente tidsskrifter som World Journal of Surgery, Lancet Global Health og Obesity Surgery. Han hadde planer om å fullføre ph.d.- studie i metabolsk kirurgi.

Han var ofte på Færøyene, både for familiebesøk og for å jobbe på Landssjúkrahúsið, for å støtte det kirurgiske miljøet der.

Vi vil huske han som modig, uredd og en som alltid var pasientens advokat. Han var alltid inkluderende og meget godt likt. Sosialt var han en del av limet på vår avdeling og alltid en positiv faktor inn i arbeidsmiljøet.

Eivind etterlater seg et stort savn og tomrom i vår avdeling. Han var et fantastisk menneske, en god venn og en uvurderlig kollega som vi er takknemlige over å ha kjent. Eivind etterlater seg samboer og to barn på henholdsvis tre år og tre måneder. Vår dypeste medfølelse går til Maibritt og resten av familien.

På vegne av alle kolleger ved Kirurgisk avdeling, Sykehuset Østfold

Publisert: 6. september 2021. Tidsskr Nor Legeforen. DOI: 10.4045/tidsskr.21.0563

(C) Tidsskrift for Den norske legeforening 2023. Lastet ned fra tidsskriftet.no 26. april 2023. 